\title{
FUNCTIONALIZED CARBON NANOTUBES AS EFFICIENT VEHICLES TO PERFORM PLASMIDIAL DNA DELIVERY TO NILE TILAPIA'S MALE GERMLINE STEM CELLS
}

Fernanda M. P. Tonelli ${ }^{*}$, Samyra M. S. N. Lacerda², Luiz O. Ladeira ${ }^{3}$, Luiz R. França ${ }^{2}$, Rodrigo R. Resende ${ }^{1}$

1 Departament of Biochemistry and Immunology, Federal University of Minas Gerais, Belo Horizonte/MG

2 Department of Morphology, Federal University of Minas Gerais, Belo Horizonte/MG

3 Department of Physics, Federal University of Minas Gerais, Belo Horizonte/MG

*e-mail: tonellinanda@gmail.com

\section{Abstract}

Male germline stem cells (MGSCs) are important cells to study because they possess a unique ability to transmit genetic information to offspring, through sperm generation. In the present study, we aimed to investigate the efficiency of gene delivery to Nile tilapia's MGSCs using different plasmidial DNA delivery strategies. Nile tilapia's MGSCs were obtained in DMEM/F12 supplemented medium after testicular enzymatic dissociation, density gradient centrifugation and differential plating. The plasmidial DNA used was the pAmCyan (Clontech). The delivery to the cells was performed by using Lipofectamine ${ }^{\circledR} 2000$ (Life Technologies), electroporation $(225 \mathrm{~V}$ and $50 \mu \mathrm{F})$ and carboxylated multiwall carbon nanotubes (fMWCNTs). After transfection, MGSC's viability was determined using the Annexin-V-Fluos Staining kit (Roche). The cyan fluorescent protein's (CFP) expression was accessed through fluorescent microscopy, 24 hours after the delivery and cells' incubation at $28^{\circ} \mathrm{C}$ and $5 \% \mathrm{CO}_{2}$. Through RT-PCR and $\mathrm{q}$-PCR the transgene and $\beta$-actin's mRNA production were compared as indicative of the MGSCs' capacity of expressing the CFP gene. Twenty-four hours after transfection, we observed expression of the cyan fluorescent protein in cultured MGSCs transfected through all delivery strategies tested. When it comes to the cytotoxicity induced by these different plasmidial DNA delivery strategies, the 
electroporation induced decrease in SSCs viability $(23,5 \%)$ at levels higher than those induced by carbon nanotubes $(1,4 \%)$ and Lipofectamine ${ }^{\circledR} 2000$ (4,8\%). The highest transcription rate of the transgene was obtained on the plasmidial DNA delivery performed by fMWCNTs. Therefore, fMWCNTs, when complexed with plasmidial DNA, can promote gene delivery to Nile tilapia's MGSCs with higher transfection efficiency than cationic lipids or electroporation, causing also less cell death.

Keywords: functionalized multiwall carbon nanotubes, male germline stem cells' transfection, Nile tilapia.

\section{Financial support: CNPq and FAPEMIG}

